\title{
Enhancement of the expression of HCV core gene does not enhance core-specific immune response in DNA immunization: advantages of the heterologous DNA prime, protein boost immunization regimen
}

\author{
Ekaterina Alekseeva*1, Irina Sominskaya1, Dace Skrastina1, Irina Egorova ${ }^{2,3}$, \\ Elizaveta Starodubova ${ }^{2}$, Eriks Kushners ${ }^{1}$, Marija Mihailova1, \\ Natalia Petrakova ${ }^{4}$, Ruta Bruvere ${ }^{1}$, Tatyana Kozlovskaya1, \\ Maria Isaguliants*2,4,5 and Paul Pumpens ${ }^{1}$
}

Address: ${ }^{1}$ Latvian Biomedical Research and Study Centre, Ratsupites 1, Riga, LV-1067, Latvia, ${ }^{2}$ Swedish Institute of Infectious Disease Control, SE17182 Stockholm, Sweden, ${ }^{3}$ Pasteur Institute, 197101 St Petersburg, Russia, ${ }^{4}$ Microbiology and Tumorbiology Center, Karolinska Institutet, 17177 Stockholm, Sweden and ${ }^{5}$ D.I. Ivanovsky Institute of Virology, 123098 Moscow, Russia

Email: Ekaterina Alekseeva* - kate@biomed.lu.lv; Irina Sominskaya - irina@biomed.lu.lv; Dace Skrastina - daceskr@biomed.lu.lv; Irina Egorova - egorovai69@mail.ru; Elizaveta Starodubova - estarodubova@gmail.com; Eriks Kushners - gaishaisrx@inbox.lv; Marija Mihailova - mary@biomed.lu.lv; Natalia Petrakova - nvpetrakova@hotmail.com; Ruta Bruvere - Bruvere@biomed.lu.lv; Tatyana Kozlovskaya - Tatyana@biomed.lu.lv; Maria Isaguliants* - maria.isaguliants@smi.ki.se; Paul Pumpens - paul@biomed.lu.lv

* Corresponding authors

\section{Published: 8 June 2009}

Genetic Vaccines and Therapy 2009, 7:7 doi:10.1186/1479-0556-7-7

This article is available from: http://www.gvt-journal.com/content/7///7

This is an Open Access article distributed under the terms of the Creative Commons Attribution License (http://creativecommons.org/licenses/by/2.0), which permits unrestricted use, distribution, and reproduction in any medium, provided the original work is properly cited.

\begin{abstract}
Background: Hepatitis $\mathrm{C}$ core protein is an attractive target for $\mathrm{HCV}$ vaccine aimed to exterminate HCV infected cells. However, although highly immunogenic in natural infection, core appears to have low immunogenicity in experimental settings. We aimed to design an $\mathrm{HCV}$ vaccine prototype based on core, and devise immunization regimens that would lead to potent anti-core immune responses which circumvent the immunogenicity limitations earlier observed.

Methods: Plasmids encoding core with no translation initiation signal ( $\mathrm{PCMVcore);} \mathrm{with} \mathrm{Kozak}$ sequence (pCMVcoreKozak); and with HCV IRES (pCMVcorelRES) were designed and expressed in a variety of eukaryotic cells. Polyproteins corresponding to HCV Ib amino acids (aa) I-98 and $1-173$ were expressed in E. coli. C57BL/6 mice were immunized with four $25-\mu \mathrm{g}$ doses of PCMVcoreKozak, or PCMV (I). BALB/c mice were immunized with $100 \mu \mathrm{g}$ of either PCMVcore, or pCMVcoreKozak, or pCMVcorelRES, or empty pCMV (II). Lastly, BALB/c mice were immunized with $20 \mu \mathrm{g}$ of core aa I-98 in prime and boost, or with $100 \mu \mathrm{g}$ of PCMVcoreKozak in prime and $20 \mu \mathrm{g}$ of core aa $\mathrm{I}-98$ in boost (III). Antibody response, $\left[{ }^{3} \mathrm{H}\right]-\mathrm{T}$-incorporation, and cytokine secretion by core/core peptide-stimulated splenocytes were assessed after each immunization.

Results: Plasmids differed in core-expression capacity: mouse fibroblasts transfected with PCMVcore, pCMVcoreIRES and PCMVcoreKozak expressed $0.22 \pm 0.18,0.83 \pm 0.5$, and $13 \pm 5 \mathrm{ng}$ core per cell, respectively. Single immunization with highly expressing PCMVcoreKozak induced specific IFN- $\gamma$ and IL-2, and weak antibody response. Single immunization with plasmids directing low levels of core expression induced similar levels of cytokines, strong T-cell proliferation
\end{abstract}


(pCMVcorelRES), and antibodies in titer $10^{3}$ (pCMVcore). Boosting with pCMVcoreKozak induced low antibody response, core-specific T-cell proliferation and IFN- $\gamma$ secretion that subsided after the 3 rd plasmid injection. The latter also led to a decrease in specific IL-2 secretion. The best was the heterologous PCMVcoreKozak prime/protein boost regimen that generated mixed ThI/Th2cellular response with core-specific antibodies in titer $\geq 3 \times 10^{3}$.

Conclusion: Thus, administration of highly expressed HCV core gene, as one large dose or repeated injections of smaller doses, may suppress core-specific immune response. Instead, the latter is induced by a heterologous DNA prime/protein boost regimen that circumvents the negative effects of intracellular core expression.

\section{Background}

Globally, an estimated 170 million people are chronically infected with hepatitis $\mathrm{C}$ virus (HCV), and 3 to 4 million persons are newly infected each year $[1,2]$. The human immune system has difficulties in clearing the virus in either the acute, or chronic phase of the infection with up to $40 \%$ of patients progressing to cirrhosis and liver failure [3-6]. Extensive studies have unraveled important reliable correlates of viral clearance [7-11]. This, together with the growing need to diminish the magnitude of HCV associated liver disease served as a basis for intensive HCV vaccine research. A series of HCV vaccine candidates have moved into clinical trials [11]. One such is the peptide vaccine IC41 consisting of a panel of MHC class I and class II restricted epitopes adjuvanted by poly-L-arginine administered to healthy volunteers [12] and to chronic HCV patients including non-responders to the standard therapy $[13,14]$. Another therapeutic vaccine employed peptides chosen individually for their ability to induce the strongest in vitro cellular response [15]. In a further vaccine trial, chronic hepatitis $\mathrm{C}$ patients received the recombinant HCV envelope protein E1 [16]. The first clinical trial of an HCV DNA vaccine consisting of a codon-optimized NS3/4A gene administered to chronic hepatitis $\mathrm{C}$ patients is currently ongoing (CHRONVAC-C ${ }^{\circledR}$; http:// www.clinicaltrials.gov/ct2/results?term=NCT00563173; http://www.bion.no/moter/Vaccine/ Matti S\%E4llberg.pdf).

So far, none of the peptide or protein vaccines were able to induce a significant improvement in the health conditions of chronic HCV patients, or a significant decrease of HCV RNA load, specifically if compared to the conventional IFN-based therapy $[13,15,16]$. The vaccine trials have, however, demonstrated that when achieved, HCV RNA decline in the vaccine recipients correlates with induction of strong IFN-gamma T-cell response [13]. Such a response can best be recruited by DNA vaccines, either alone or with the aid of heterologous boosts [11,17]. Indeed, vaccination of chimpanzees showed the ability to elicit effective immunity against heterologous HCV strains using T-cell oriented HCV genetic vaccines that stimulated only the cellular arm of the immune system $[17,18]$.
An attractive target for HCV vaccine is the nucleocapsid (core) protein [19-21]. It is highly conserved among various HCV genotypes with amino acid homology exceeding $95 \%[21,22]$. Core binds and packages the viral genomic RNA, regulates its translation [23-26] and drives the production of infectious viruses [27-29]. Core contributes to HCV persistence also indirectly by interfering with host cell transcription, apoptosis, lipid metabolism, and the development of immune response [30-33]. Extermination of core expressing cells and inhibition of the activity of extracellular core (non-enveloped particles containing HCV RNA [34]) could be highly beneficial.

Ideally, HCV core could be eliminated by a specific vaccine-induced immune response. It is a strong immunogen with anti-core immune response evolving very early in infection $[35,36]$. Early and broad peripheral and intrahepatic CD8+ T-cell and antibody response to core/core epitopes is registered in chimpanzees controlling $\mathrm{HCV}$ infection HCV, but not in chimpanzees that become chronically infected [37-39]. In mice, potent experimentally induced anti-core immune response conferred partial protection against challenge with core expressing recombinant vaccinia virus [40]. However, despite high immunogenicity in the natural infection, core does not perform well as an immunogen, specifically if introduced as naked DNA [2,41-43]. Attempts to enhance core immunogenicity by targeting HCV core protein to specific cellular compartments [44], co-immunization with cytokine expressing plasmids [2,41], adjuvants as CpG [45], or truncated core gene versions [46] had limited or no success.

Prime-boost strategies have been used to increase immune responses to a number of DNA vaccines. Immunization regimens comprised of a DNA prime and a viral vector boost for instance for vaccinia virus $[47,48]$, adenovirus [49], fowlpox [50,51], and retrovirus [52]. Priming with DNA and boosting with protein is another promising approach. This regimen has been studied for HIV $[53,54]$, hepatitis C virus [55,56], anthrax [57], Mycobacteria [58,59], Streptococcus pneumoniae [60] and BVDV [61]. DNA vaccines and recombinant protein vaccines utilize 
different mechanisms to elicit antigen-specific responses. Due to the production of antigen in transfected cells of the host, a DNA vaccine induces robust T-cell responses, which are critical for the development of T-cell-dependent antibody responses [62]. DNA immunization is also highly effective in priming antigen-specific memory B cells. In contrast, a recombinant protein vaccine is generally more effective at eliciting antibody responses than cell-mediated immune responses and may directly stimulate antigen-specific memory B cells to differentiate into antibody-secreting cells, resulting in production of high titer antigen-specific antibodies [63]. Therefore, a DNA prime plus protein boost is a complementary approach that overcomes each of their respective shortcomings. Certain improvement of the immune response was reached after co-delivery of HCV core DNA and recombinant core $[2,40,64]$. In this study, we have shown that in DNA immunization, poor core-specific immune response can be a consequence of high levels of intracellular core expression, and that such a response can be improved by using low-expressing core genes, or single core gene primes in combination with recombinant core protein boosts.

\section{Methods \\ Plasmids for expression of $\mathrm{HCV}$ core}

Region encoding aa 1-191 of HCV core was reverse-transcribed and amplified from HCV 1b isolate 274933RU (GeneBank accession \#AF176573) [65] using oligonucleotide primers: sense GATCCAAGCTTATGAGCACGAATCC and antisense GATCCCTCGAGTCAAGCGGAAGCTGG containing recognition sites of HindIII and XhoI restriction endonucleases. The amplified DNA was cleaved with HindIII/XhoI and inserted into pcDNA3 (Invitrogen, USA) cleaved with HindIII/XhoI resulting in pCMVcore. Region encoding aa 1-191 of HCV core was also reverse-transcribed and amplified from HCV isolate 274933RU using another set of primers that carried Kozak consensus sequence sense AGCTGCTAGCGCCGCCACCATGAGCACGAATCCT and antisense GATCGTTAACTAAGCGGAAGCTGGATGG primers containing recognition sites of restriction endonucleases NheI and XhoI, respectively. The amplified DNA was cleaved with NheI/KspAI and inserted into the plasmid pCMVE2/p7-2 [66] cleaved with NheI/XhoI, resulting in pCMVcoreKozak. The region corresponding to HCV 5'UTR, and coding sequences for aa 1-809 was reverse-transcribed and amplified from HCV $1 \mathrm{~b}$ isolate AD78P1 (GeneBank accession \#AJ132997) [67], kindly provided by Prof. M. Roggendorf (Essen, Germany) using sense-GACCCAAGCTTCGTAGACCGTGCACCAT and antisense CATGCTCGAGTTAGGCGTATGCTCG primers. The amplified DNA was cleaved with HindIII/XhoI and inserted into pcDNA3 cleaved with HindIII/XhoI resulting in pCMVcoreIRES. HCV 274933RU core differed from
HCV AD78P1 core in positions 70 (H versus $\mathrm{R}$ ), 75 (T versus $A$ ), and 147 (V versus $T$ ), respectively.

Growth of pcDNA3, pCMVcore, pCMVcoreKozak, and pCMVcoreIRES was accomplished in the E. coli strain DH5alpha. Plasmid DNA was extracted and purified by Endo Free plasmid Maxi kit (Qiagen GmbH, Germany). The purified plasmids were dissolved in the phosphate buffered saline (PBS) and used for in vitro expression assays and for DNA immunization.

\section{Cell transfection, lysis and Western-blotting}

BHK-21, COS-7, and NIH3T3 cells were seeded into plates $\left(3 \times 10^{5}\right.$ cells/well) and transfected by plasmid DNA ( 2 $\mu \mathrm{g})$ using Lipofectamine (GIBCO-BRL, Scotland) or ExGen 500 (Fermentas, Lithuania) as described by the manufacturers. HCV core expression was analyzed 24, 48 and $72 \mathrm{~h}$ post transfection. Cells were lysed for $10 \mathrm{~min}$ at $0^{\circ} \mathrm{C}$ in the buffer containing $50 \mathrm{mM}$ Tris- $\mathrm{HCl}, \mathrm{pH} 7.5,1$ $\mathrm{mM}$ EDTA, $1 \mathrm{mM}$ PMSF and 1\% NP-40. Lysates were cleared by $10 \mathrm{~min}$ centrifugation at $6000 \mathrm{~g}$, resolved by $12 \%$ SDS-PAAG, and transferred to PVDF membranes (Amersham Pharmacia Biotech, Ireland). HCV core expression was detected by immunostaining with polyclonal rabbit anti-core antibodies [68], and secondary horseradish peroxidase (HRP)-conjugated anti-rabbit immunoglobulins (Amersham Pharmacia Biotech, Ireland) followed by ECL ${ }^{\mathrm{TM}}$ detection (ECL Plus, Amersham Pharmacia Biotech, Ireland).

\section{Quantification of core expression in mouse cells}

NIH3T3 cells were transfected with either pcDNA3, pCMVcore, pCMVcoreKozak, pCMVcoreIRES, or pEGFP-N1 (Clontech, CA, USA). The percent of transfection was evaluated by counting the number of GFP expressing cells per 500 transfected NIH3T3 cells using a fluorescence Leica DM 6000 microscope (Leica Camera AG, Germany). Cells were harvested $48 \mathrm{~h}$ post-transfection, counted, and $10^{4}$ cells were lysed in $2 \times$ SDS Sample buffer. Lysates and samples containing 1 to $50 \mathrm{ng}$ of recombinant core aa 1-173 (corresponding to p21) were run simultaneously on $12 \%$ SDS-PAAG and transferred onto PVDF membrane for calibration. Blots were blocked overnight in PBS-T with 5\% non-fat dry milk, stained with polyclonal anti-core antibodies \#35-6 (1:5000) followed by the secondary antirabbit HRP-conjugated antibodies (DAKOPatts AB, Denmark). Signals were detected using the $\mathrm{ECL}^{\mathrm{TM}}$ system (Amersham Pharmacia Biotech, Ireland). X-ray films were scanned, and processed using Image J software http:// rsb.info.nih.gov/ij. The data are presented as the Mean Grey Values (MGV). The core content was quantified by plotting the MGV of each sample onto a calibration curve prepared using recombinant core aa 1-173. After core detection, blots were striped according to the ECL protocol and re-stained with monoclonal anti-tubulin antibod- 
ies (Sigma, USA) and secondary anti-mouse HRPconjugated antibodies (DAKOPatts AB, Denmark). Core content per transfected cell was evaluated after accounting for the percent of transfection and normalization to the tubulin content per well.

\section{Immunofluorescence staining}

BHK-21 cells were seeded on the chamber slides (Nunc International, Denmark) and transfected as above. $24 \mathrm{~h}$ post transfection, the slides were dried, fixed with acetic acid and ethanol (1:3) for $15 \mathrm{~min}$ and rinsed thoroughly in distilled water. Fixed cells were re-hydrated in PBS, and incubated for $24 \mathrm{~h}$ at $4{ }^{\circ} \mathrm{C}$ with anti-HCV core rabbit polyclonal antibodies (1:50) in the blocking buffer (PBS with $2.5 \mathrm{mM}$ EDTA and 1\% BSA). Secondary antibodies were goat anti-rabbit immunoglobulins labeled with TRITC (1:200; DAKO, Denmark). Slides were then mounted with PermaFluor aqueous mounting medium (Immunon, Pa., USA) and read using a fluorescence microscope.

\section{Recombinant HCV-core proteins and core-derived peptides}

Peptides covering core amino acids 1-18, 1-20, 23-43, $34-42,133-142$ and a control peptide TTAVPWNAS from gp41 of HIV-1 were purchased from Thermo Electron $\mathrm{GmbH}$ (Germany). Core proteins representing aa 1-152 of HCV 274933RU and aa 1-98, and 1-173 of AD78P1 were expressed in E. coli and purified by chromatography as was described earlier $[69,70]$. Purified proteins were dissolved in PBS.

\section{Mice and immunization}

The following immunizations were performed:

\section{Scheme I}

Groups of 12 female 8-week old C57BL/6 mice (Stolbovaya, Moscow Region, Russia) were immunized with a total of $100 \mu \mathrm{g}$ of pCMVcoreKozak, or empty vector, split into four i.m. injections done with 3-4 week intervals. Control mice were mock-immunized with PBS.

\section{Scheme II}

Female 6-8 week old BALB/c mice (Animal Breeding Centre of the Institute of Microbiology and Virology, Riga) had injected into their Tibialis anterior (TA), $50 \mu \mathrm{l}$ of 0.01 $\mathrm{mM}$ cardiotoxin (Latoxan, France) in sterile $0.9 \% \mathrm{NaCl}$ five days prior to immunization. Groups of 6 to 7 mice were immunized with a single $100 \mu \mathrm{g}$ dose of either pCMVcoreIRES, or pCMVcore, or pCMVcoreKozak, or empty vector, all dissolved in $100 \mu \mathrm{l}$ PBS, applied intramuscularly (i.m.) into the cardiotoxin-treated TA. Control mice were left untreated.

\section{Scheme III}

Groups of 5 to 6 female 6-8 week old BALB/c mice pretreated with cardiotoxin, were injected i.m. with $100 \mu \mathrm{g}$ of pCMVcoreKozak and boosted three weeks later with $20 \mu \mathrm{g}$ of core aa 1-98 in PBS, or primed and boosted subcutaneously with $20 \mu \mathrm{g}$ of core aa 1-98 in PBS. Control animals were left untreated.

\section{ELISA}

Mice were bled from retro-orbital sinus prior to, and 2 to 3 weeks after each immunization, or 5 weeks post a single gene immunization (in Scheme II). Peptides corresponding to core aa 1-20, 23-43 or 133-142 were coated onto 96-well MaxiSorp plates (Nunc, Denmark), and recombinant core aa 1-98, 1-152, or 1-173, on the 96-well PolySorp plates (Nunc, Denmark). Coating was done overnight at $4{ }^{\circ} \mathrm{C}$ in $50 \mathrm{mM}$ carbonate buffer, $\mathrm{pH} 9.6$ at antigen concentration of $10 \mu \mathrm{g} / \mathrm{ml}$. After blocking with PBS containing $1 \% \mathrm{BSA}$ for $1 \mathrm{~h}$ at $37^{\circ} \mathrm{C}$, serial dilutions of mouse sera were applied on the plates and incubated for an additional hour at $37^{\circ} \mathrm{C}$. Incubation was followed by three washings with PBS containing 0.05\% Tween-20. Afterwards, plates were incubated with the horseradish peroxidase-conjugated anti-mouse antibody (Sigma, USA) for $1 \mathrm{~h}$ at $37^{\circ} \mathrm{C}$, washed, and substrate OPD (Sigma, USA) added for color development. Plates were read on an automatic reader (Multiscan, Sweden) at $492 \mathrm{~nm}$. ELISA performed on plates coated with core aa 1-98, 1152 , or 1-173 showed similar results (data not shown). Immune serum was considered positive for anti-core antibodies whenever a specific OD value exceeded, by at least two-fold, the signals generated by: pre-immune serum reacting with core-derived antigen, and by immune serum reacting with BSA-coated plate, the assays performed simultaneously.

\section{T-cell proliferation assay}

For T-cell proliferation tests, mice were sacrificed and spleens were obtained two weeks after each immunization in Scheme I; and three and five weeks after the last immunization in Schemes II and III. Murine splenocytes were harvested using red blood cell lysing buffer (Sigma, USA), single cell-suspensions were prepared in RPMI 1640 supplemented with $2 \mathrm{mM}$ L-Glutamine and 10\% fetal calf serum (Gibco BRL, Scotland) at $6 \times 10^{6}$ cells $/ \mathrm{ml}$. Cell were cultured in U-bottomed microculture plates at $37^{\circ} \mathrm{C}$ in a humidified $5 \% \mathrm{CO}_{2}$ chamber (Gibco, Germany). Cell stimulation was performed with peptides representing core aa 1-20, 23-43, 34-42 and recombinant core aa $1-98,1-152$, and aa $1-173$ at dilutions to 3.1, $6.25,12.5,25.0,50.0$, and $100 \mu \mathrm{g} / \mathrm{ml}$, all in duplicate. Concanavalin A (ConA) was used as a positive control at $2 \mu \mathrm{g} / \mathrm{ml}$. Cells were grown for $72 \mathrm{~h}$, after which $\left[{ }^{3} \mathrm{H}\right]$-thymidine $(1 \mu \mathrm{Ci}$ per well; Amersham Pharmacia Biotech, Ireland) was added. After an additional $18 \mathrm{~h}$, cells were 
harvested onto cellulose filters and the radioactivity was measured on a beta counter (Beckman, USA). The results were presented as stimulation indexes (SI), which were calculated as a ratio of mean cpm obtained in the presence and absence of a stimulator (protein or peptide). Emptyvector immunized and control mice showed SI values of $0.8 \pm 0.4$. SI values $\geq 1.9$ were considered as indicators of specific T-cell stimulation.

\section{Quantification of cytokine secretion}

For detection of cytokines, cell culture fluids from T-cell proliferation tests were collected, for IL-2 - $24 \mathrm{~h}$, and for IL- 4 and IFN- $\gamma-48 \mathrm{~h}$ post the on-start of T-cell stimulation. Detection of cytokines in the cell supernatants was performed using commercial ELISA kits (Pharmingen, BD Biosciences, CA, USA) according to the manufacturers' instructions.

\section{Results}

\section{Cloning and expression}

Plasmids were constructed encoding core of HCV $1 \mathrm{~b}$ isolate 274933RU without translation initiation signals (pCMVcore); and with Kozak translation initiation signal (pCMVcoreKozak). Core with viral translation initiation signal IRES taken in the natural context was derived from HCV 1b isolate AD78P1 [67]. Viral cores had a minimal sequence difference in positions 70,75 , and 147 , all three cases representing homologous substitutions.

Expression from these plasmids was tested both in vitro and in cell cultures. Plasmids pCMVcore and pCMVcoreKozak were used as the templates for the T7-driven mRNA transcription; mRNA was translated in vitro in the rabbit reticulocyte lysate system. Both mRNAs generated a translation product of approximately $23 \mathrm{kDa}$ corresponding to the molecular mass of unprocessed HCV core (p23; data not shown). Next, core-expressing vectors were used to transfect a series of mammalian cell lines. Western blotting of BHK-21 and COS-7cells transfected with pCMVcore, pCMVcoreKozak and pCMVcoreIRES using corespecific antibodies demonstrated an accumulation of proteins with the expected molecular mass of $21 \mathrm{kDa}$ that corresponds to core aa 1-171 cleaved from the full-length core by cellular proteases [71,72] (Fig. 1). Minimal amounts of p23 were also detected, specifically after transfections of BHK-21 with pCMVcore and pCMVcoreIRES (Fig. 1). The overall level of HCV core synthesis in BHK21 cells was somewhat higher than in COS-7 cells (Fig. 1). In both cell lines, the highest level of core expression was achieved with pCMVcoreKozak (Fig. 1, 2). All cells expressing core and immunostained with core-specific antibodies demonstrated cytoplasmic granular staining characteristic of the processed p 21 form of HCV core [7274] (Fig. 2).
The expression capacity of the vectors was quantified in murine fibroblasts to reproduce DNA immunization that was to be done in mice. Core expression was assessed on Western blots of SDS-PAAG resolving lysates of NIH3T3 transfected with core expressing and control plasmids (Fig. 3A and 3B). Images of Western blots were processed using the ImageJ software and individual bands were represented in arbitrary units (Mean Grey Values, MGV). Their correspondence to core quantity was established using calibration curves built with the use of recombinant core aa 1-173 (see Additional file 1) after normalization to the percent of transfection and protein content of the samples. Plasmid pCMVcore with no translation initiation signals provided the lowest level of core expression (Fig. 3B). IRES promoted a two-fold increase, and the Kozak sequence, a 35-fold increase of core expression with > 15 ng of protein produced per expressing cell (Fig. $3 B)$.

\section{Immunization of mice with HCV core DNA}

All plasmids were purified by standard protocols in accordance with a GLP practice for preparation of DNA vaccines, and used in a series of mouse immunization experiments.

\section{HCV core DNA in priming and boosts}

Plasmid directing the highest level of core expression was selected and a pilot experiment defining the strategy of DNA immunization was performed. C57BL/6 mice were immunized four times with $25 \mu \mathrm{g}$ of pCMVcoreKozak, and core-specific antibody and cellular responses were evaluated. No specific response was registered after the $1^{\text {st }}$ injection (data not shown). The immune response generated after the following three boosts is illustrated by Fig. 4 . Three injections of $25 \mu \mathrm{g}$ led to no increase of core-specific IgG response over the initial levels achieved after the first two plasmid injections (Fig. 4A). Three plasmid injections generated a better $\mathrm{T}$-cell proliferative response to core and core-derived peptides than two. However, the response could not be boosted further (Fig. 4B). IFN- $\gamma$ and IL-2 response to core was also boostable. However again, no boosting was seen after the initial two pCMVcoreKozak injections (Fig. 4C). Furthermore, the repeated injections led to a significant decrease of IL-2 secretion in response to splenocyte stimulation by recombinant core and peptides representing core $\mathrm{N}$-terminus $(\mathrm{p}<0.05$; Fig. $4 \mathrm{~B}$, and data not shown). Core-specific IL-4 secretion was not detected.

Thus, the development of core-specific immune responses occurred within six weeks after the on-start of immunization; repeated boosts with HCV core gene did not lead to a significant enhancement of core-specific immunity. 


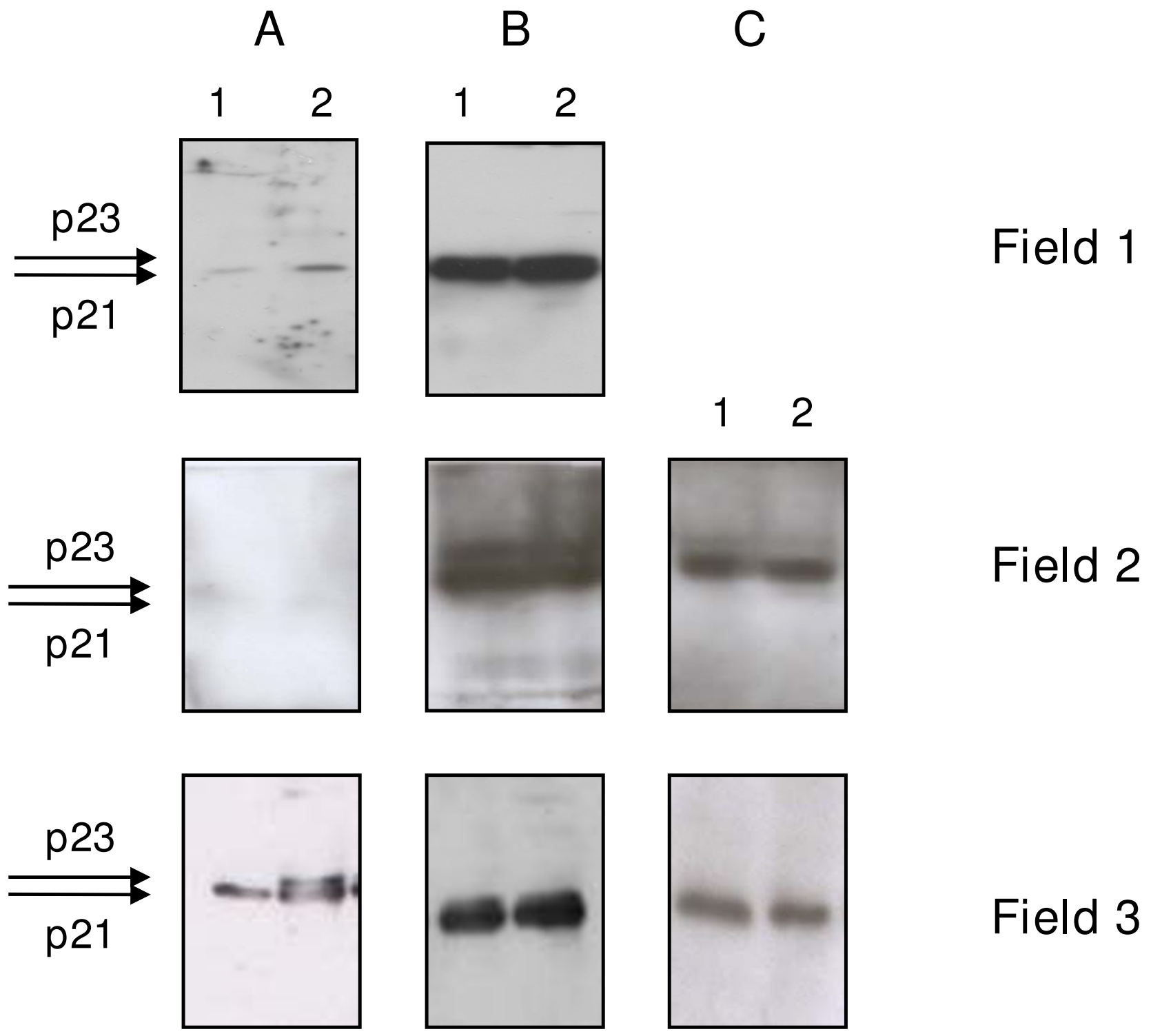

Figure I

Expression of HCV core proteins. Expression of HCV core protein directed by pCMVcore (A), pCMVcoreKozak (B), PCMVcorelRES (C) in COS-7 cells $72 \mathrm{~h}$ post-transfection (Field I); in BHK-2I cells $48 \mathrm{~h}$ (Field 2 ) and $72 \mathrm{~h}$ post transfection (Field 3). Transfection with the recommended amount (lane I), and two-fold excess of transfection reagent (lane 2).

HCV core DNA as a single injection

In the next series of experiments, we selected BALB/c mice as a strain that is expected to support a better Th2-type response with stronger antibody production [75]. Plasmid pCMVcore Kozak was given as a single $100 \mu \mathrm{g}$ injection with the effect of repeated intramuscular DNA boosts substituted by pre-treatment of the injection sites by cardiotoxin [76]. T-cell proliferative response, antibody production and cytokine secretion were monitored two and five weeks after immunization.
Significant responses in the form of core-specific IFN- $\gamma$ and IL-2 secretion exceeding the background levels in empty-vector-immunized mice were detected five weeks after a single administration of HCV core gene (Fig.5). Immunization generated no core-specific T-cell response and a low titer of core-specific IgG. Antibody response against HCV core has already been shown to develop slowly [46], mirroring the development of anti-core antibody response in HCV infected individuals [77]. Here as well, a slow increase in the level of anti-core antibodies 
A
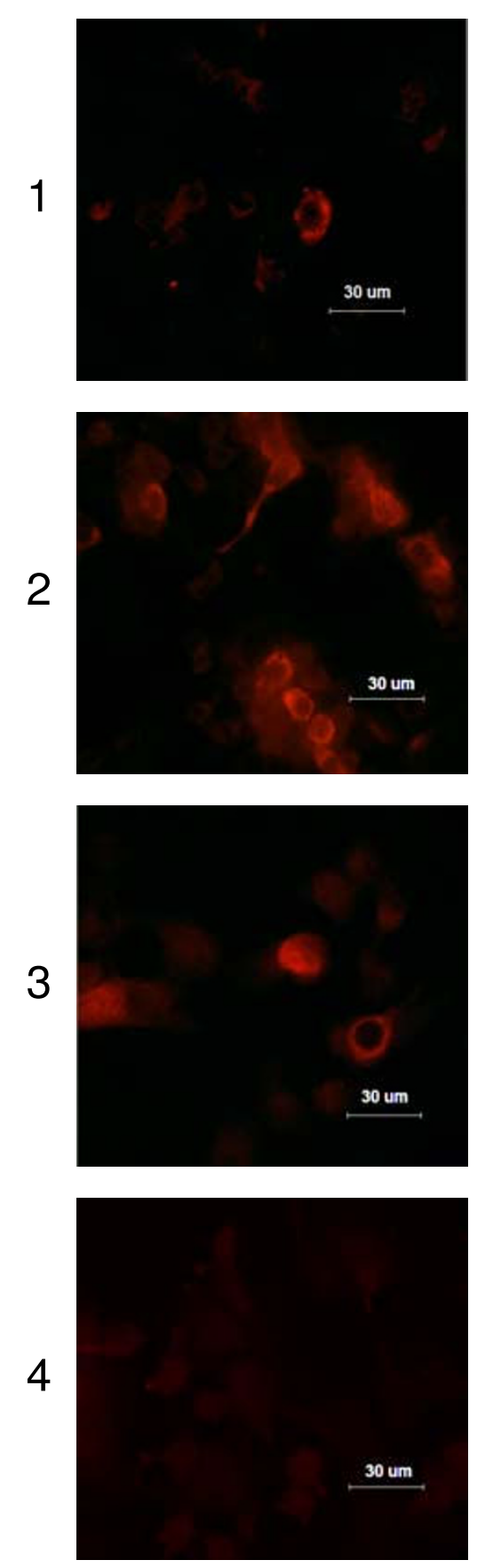

B
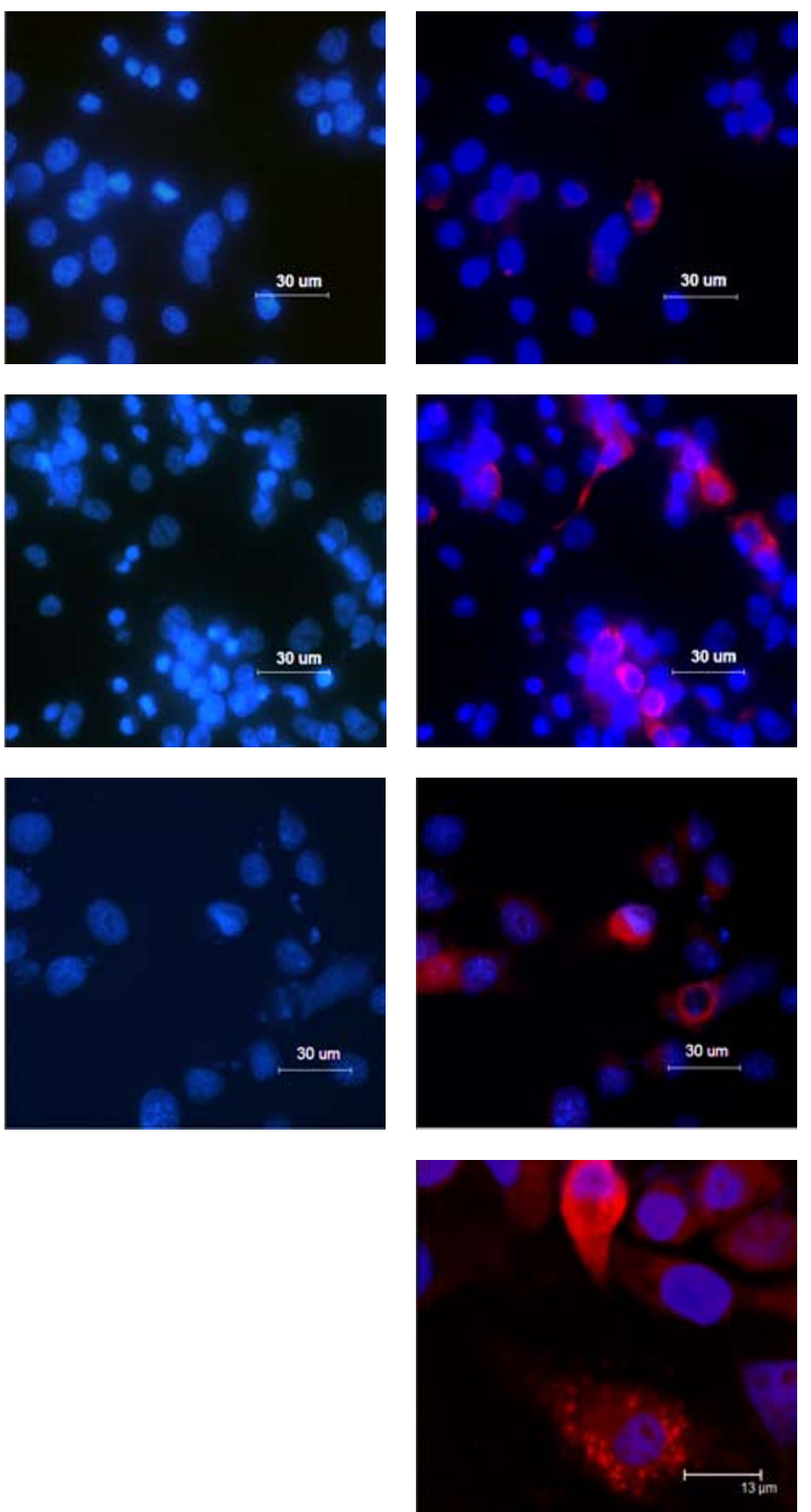

\section{Figure 2}

Immunocytochemical detection of HCV core proteins. Immunocytochemical detection of HCV core expression after transfection of BHK-2I cellswith pCMVcore (AI-CI), pCMVcoreKozak (A2-C2, C4), pCMVcorelRES (A3-C3); nontransfected BHK-2I cells (A4). Immunostaining for HCV core protein using rabbit polyclonal anti-HCVcore antibody 35-7 as primary and TRITC-conjugated anti-rabbit immunoglobulin (IgG) as secondary antibody (panel A); nuclear staining by DAPI (panel $B$ ); overlay of $A$ and $B$ (panel C); negative control (nontransfected BHK-2I cells) after staining (A4). Fluorescent images AI-4, $\mathrm{BI}-3, \mathrm{Cl}-3$ and A4 were taken with Leica DM $6000 \mathrm{~B}$ microscope and a Leica DFC 480 camera, and confocal image of cells transfected with pCMVcoreKozak and showing cytoplasmic, granular distribution (C4) with a Leica TCS SP2 SE. 

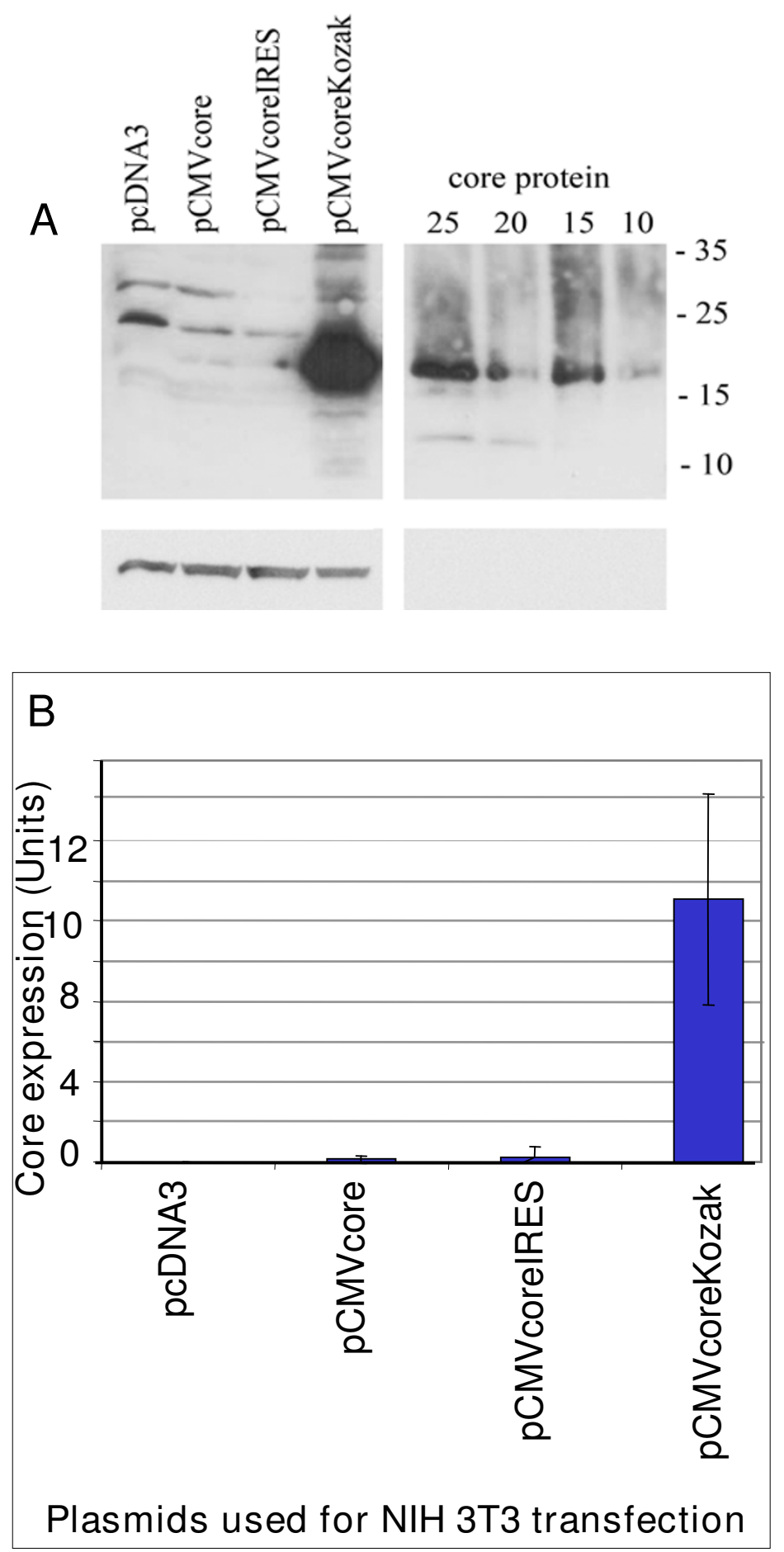

\section{Figure 3}

Expression of proteins in mouse fibroblasts NIH 3 T3 $48 \mathrm{~h}$ post-transfection. A calibration curve was prepared using recombinant core protein aa $\mathrm{I}-173$ loaded in amounts of 25, 20, I5, and $10 \mathrm{ng}$ per well (lanes 5, 6, 7 and 8, respectively). Western blotting was done using rabbit anti-core antibodies [82] (A). ECL photos of blots were scanned, and images were quantified with ImageJ software http://rsb.info.nih.gov/ij. The results of quantification of HCV core expression in four independent experiments (B). 

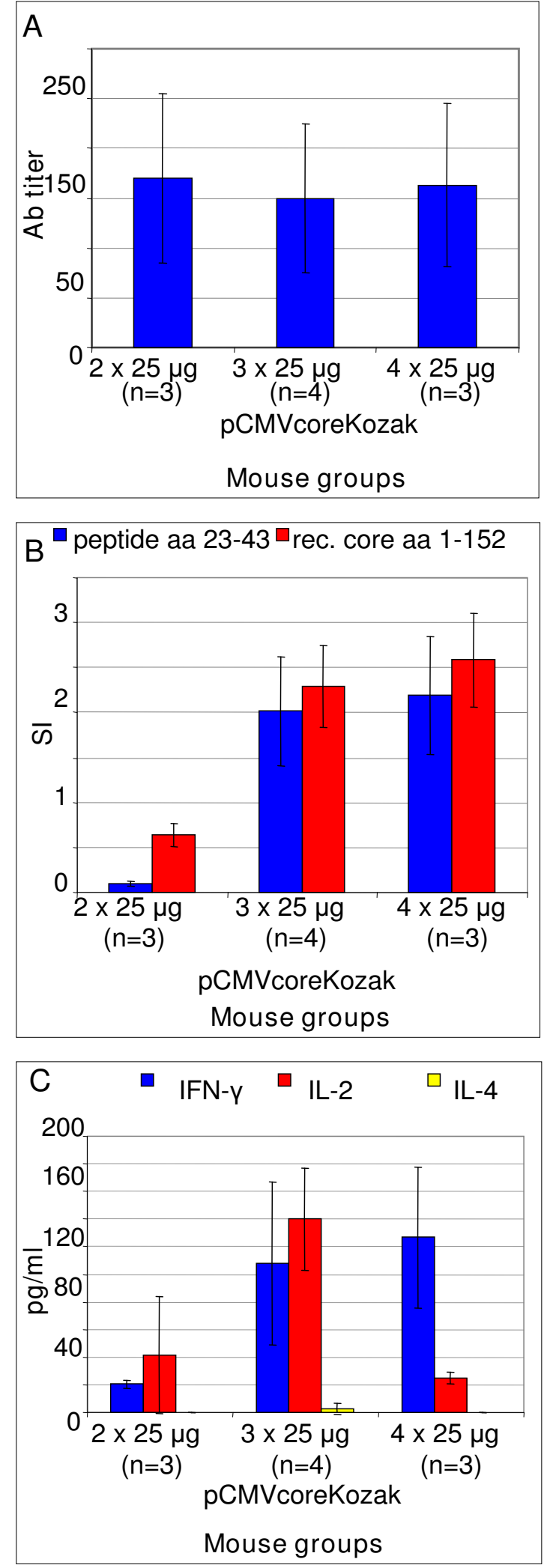

Figure 4

\begin{abstract}
Figure 4
Core-specific immune response in C57BI/6 mice receiving $2(2 \times 25 \mu \mathrm{g}), 3(3 \times 25 \mu \mathrm{g})$, and $4(4 \times 25 \mu \mathrm{g})$ injections of pCMVcoreKozak. Maximal titers of lgG specific to recombinant core and a peptide representing core aa I-20 (A); T-cell proliferation measured as the stimulation index (SI) in response to $\mathrm{HCV}$ core $(\mathrm{I}-173)$ and a peptide pool covering aa 23-43 of HCV core (B); cytokine secretion $(\mathrm{pg} / \mathrm{ml})$ in response to recombinant $\mathrm{HCV}$ core $(\mathrm{C})$. Data are average values for mice assayed at a given time point.
\end{abstract}

was observed 35 days after a single gene injection as compared to levels detected at day 21 (data not shown). There was no difference between $\mathrm{BALB} / \mathrm{C}$ and $\mathrm{C} 57 \mathrm{BL} / 6$ mice with respect to core-specific IFN- $\gamma$ secretion (Fig. $4 \mathrm{C}$ versus Fig. 5C), or core-specific IgG production ( $\mathrm{p}>0.05$ Mann Whitney U-test; Fig. 4A versus Fig. 5A and Additional file 1).

High core gene expression affects core-specific immune response The magnitude of anti-core response suggested that the increase of $\mathrm{HCV}$ core gene dose either by one-time large dose injection, or by repeated injections of smaller doses, did not significantly enhance core-specific immunity. To delineate if that could be influenced by core expression level, BALB/c mice were immunized with a single dose of low-expressing core genes with no translation initiation signals (pCMVcore), or with IRES (pCMVcoreIRES). The results were compared to immunization with core gene regulated by the Kozak sequence (pCMVcoreIRES) (Fig. $5)$. The T-cell proliferative response to core- and corederived peptides was stronger in mice immunized with pCMVcoreIRES (Fig. 5). The highest anti-core IgG response was raised in mice immunized with pCMVcore that directed the lowest level of HCV core expression (Fig. 3; Fig. 5A). It was significantly higher than the antibody response induced by $\mathrm{pCMVcoreKozak}(\mathrm{p}<0.05)$; the immune response in pCMVcoreIRES-immunized mice was intermediate (Fig. 5A). The T-cell proliferative response to core- and core-derived peptides was stronger in mice immunized with pCMVcoreIRES (Fig. 5B; $\mathrm{p}<$ $0.05)$. While IL-2 secretion was somewhat higher in mice immunized with highly expressing pCMVcoreKozak, both DNA immunogens provided a similar level of core-specific IFN- $\gamma$ secretion (Fig. 5C).

Heterologous DNA prime-protein boost regimen

We aimed to see if core-specific immune response could be enhanced without increasing core gene doses, but instead by using the heterologous prime-boost immunization regimens. HCV core protein aa 1-98 and pCMVcoreKozak were used to immunize BALB/c mice either separately, or in the DNA prime-protein boost regimen. A 

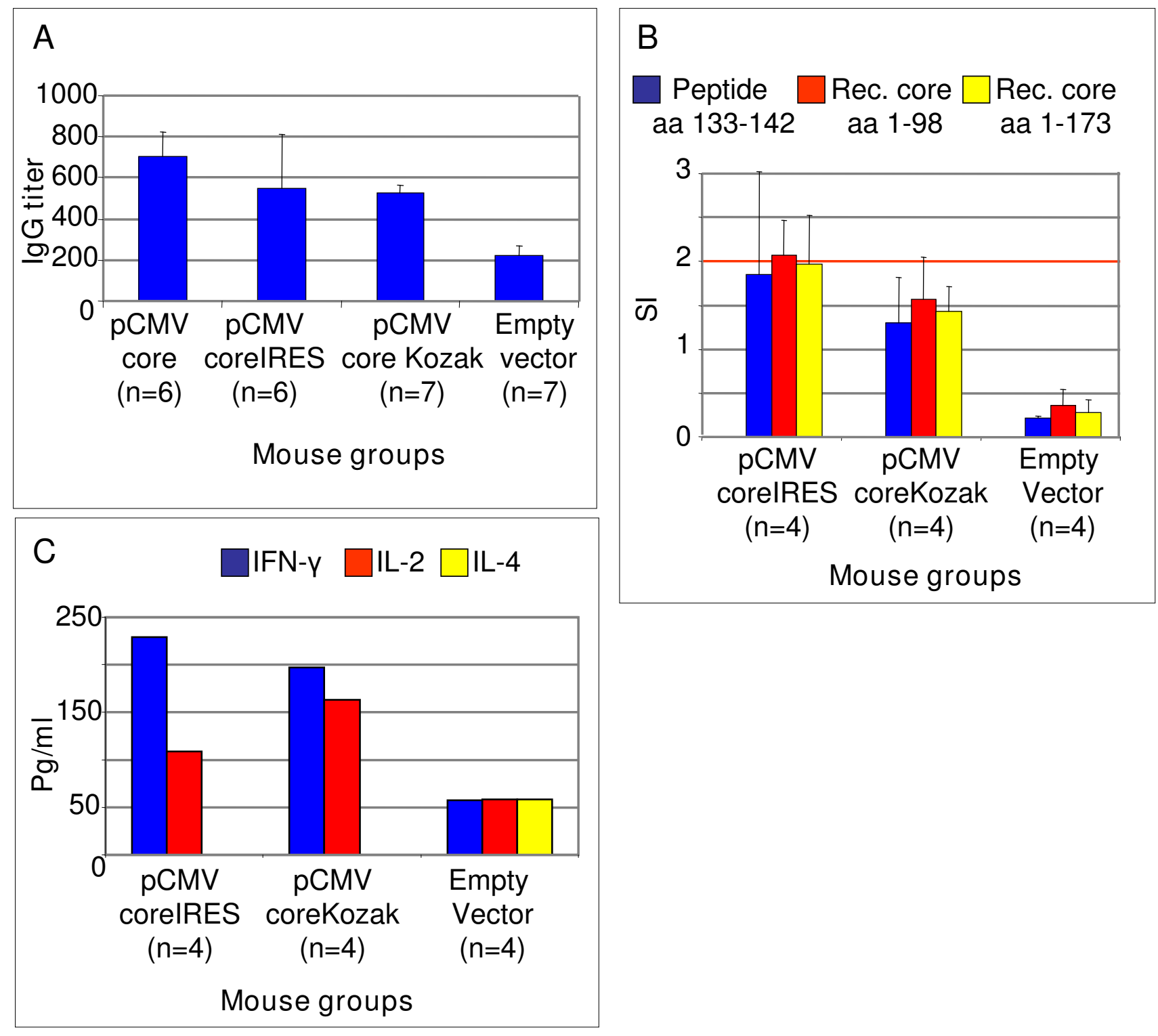

\section{Figure 5}

Core-specific immune response in BALB/c mice immunized with one $100 \mu \mathrm{g}$ dose of pCMVcoreKozak $(\mathrm{n}=7)$, pCMVcorelRES $(n=6)$, pCMVcore $(n=6)$, and empty vector $(n=7)$. The highest titers of lgG specific to core reached throughout immunization $(\mathrm{A})$; $\mathrm{T}$-cell proliferation measured as the stimulation index (SI) in response to recombinant HCV cores aa I-98 and aa I-I73 and peptide representing HCV core aa I33-I42 (B); the levels of core-specific IFN- $\gamma$, IL-2, and IL-4 secretion in the cell culture fluids collected after splenocyte stimulation with HCV core aa I-98 (C). Cytokine secretion in BALB/c mice is represented by the amounts detected in the pooled cell culture fluids from the T-cell proliferation test; therefore, no standard deviations are presented. 

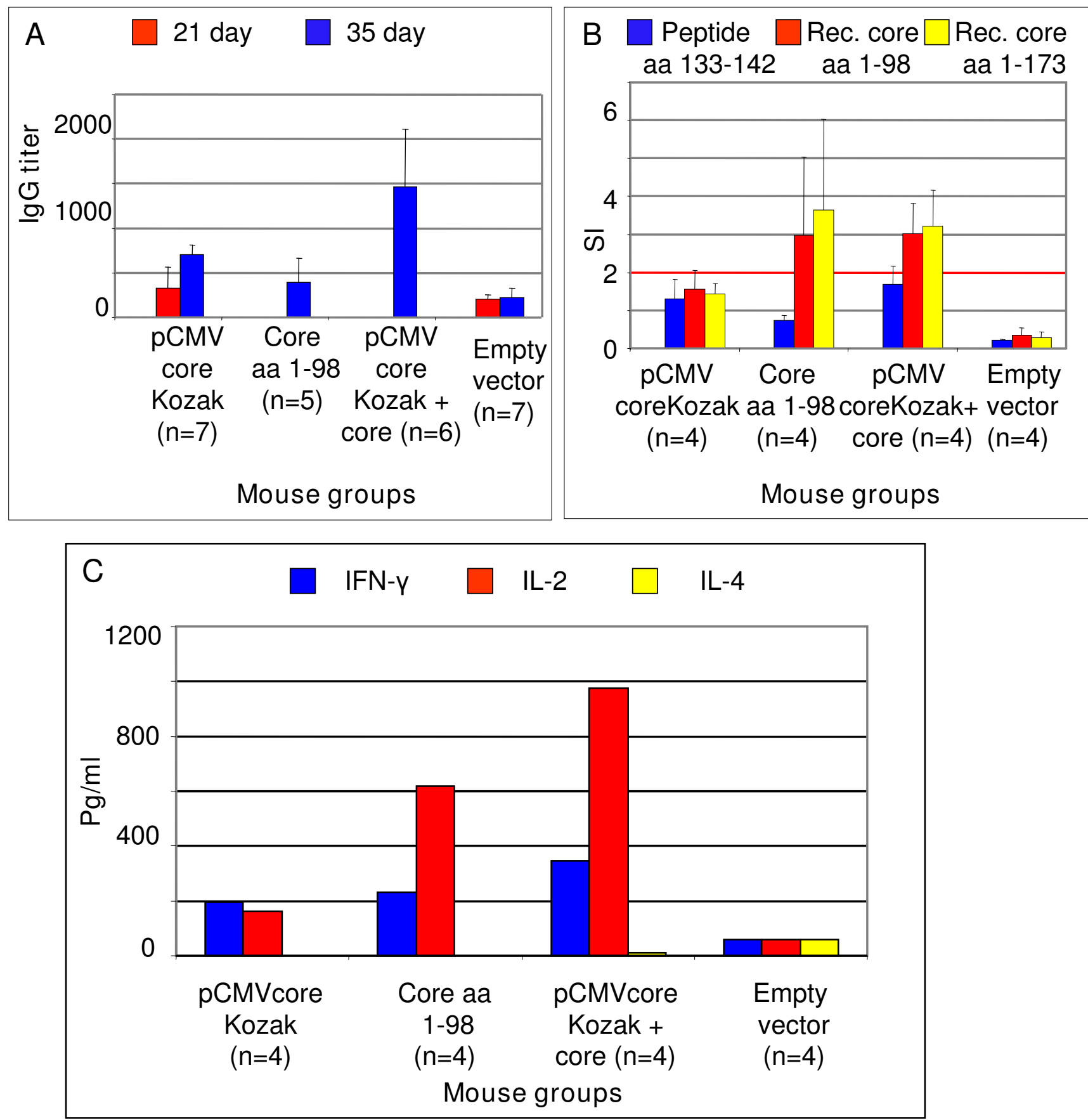

Figure 6

Core-specific immune response in BALB/c mice immunized with the recombinant $\mathbf{N}$-terminal domain of HCV core aa I-98 alone $(n=5)$; with pCMVcoreKozak $(n=7)$; and primed with pCMVcoreKozak and boosted with HCV core aa I-98 $(\mathbf{n}=\mathbf{6})$. The kinetics of IgG response to core aa I-98 (A);-T-cell proliferation measured as the stimulation index $(\mathrm{SI})$ in response to $\mathrm{HCV}$ core aa $\mathrm{I}-98$, recombinant core aa $1-173$, and a peptide covering $\mathrm{HCV}$ core aa $133-142$ (B); levels of core-specific IFN- $\gamma$ and IL-2 secretion $(\mathrm{pg} / \mathrm{ml})$ in the pooled cell culture after splenocyte stimulation with $\mathrm{HCV}$ core aa $\mathrm{I}-98$ or aa $\mathrm{I}-173$ (C). 
high titer of core-specific antibodies was achieved only after the heterologous boost (Fig. 6A). The heterologous regimen effectively induced a proliferative response, both in SI values (p levels 0.034, Mann Whitney U-test) and in the number of positive T-cell proliferation tests ( $\mathrm{p}$ level 0.014 ; Fig. 6B); and potent core-specific IFN- $\gamma$ and IL-2 secretion (Fig. 6C). Core-specific IL-4 secretion was, in all cases, very low.

Heterologous regimen induced significant anti-core antibody production (Fig. 6A). Sera of mice primed with pCMVcoreKozak and boosted with core aa 1-98 were analysed for the presence of anti-core antibodies of IgG, IgG1, IgG2a, IgG2b and IgM subclasses, and the results were compared to seroreactvivity in mice immunized with single injection of core or core expressing plasmids (Fig. 7). Mice primed with pCMVcoreKozak and boosted with core protein had significantly higher levels of anti-core IgG than mice immunized with pCMVcoreKozak $(\mathrm{p}=0.0006$, Mann-Whitney U-test) or pCMVcore ( $\mathrm{p}=0.002)$ (immunization with pCMVcore gave higher level of IgG than immunization with pCMVcoreKozak, p < 0.05). Group with heterologous prime/boost regimen had also an increased levels of anti-core IgG1, although the difference with the control group did not reach the level of significance ( $\mathrm{p}<0.1$ ). Antibodies of IgG2a or IgG2b subclasses were not found. Low specific anti-core $\operatorname{IgM}$ were observed only in mice immunized with recombinant core aa 1-98 ( $\mathrm{p}<0.1$; Fig. 7 ). It was higher than in mice primed with core DNA and boosted with core protein (p level 0.05). At the same time, core-immunized mice had no anti-core IgG1 or IgG2 (Fig. 7). Thus, the heterologous core DNA prime/core protein boost regimen preferentially induced anti-core IgG, while protein immunization triggered mostly low-level anti-core IgM.

\section{Discussion}

The immune response in DNA immunization depends on the amount of antigen produced from the immunogen in vivo as predetermined by the gene dose and by the gene capacity to direct an efficient antigen expression $[78,79]$. Normally, the response increases with the increase of the dose and efficacy of gene expression (for examples, see [80-83]). However, the DNA immunogen used here encodes not just a structural component of the virus, but also a pathogenic factor. HCV core protein interacts with

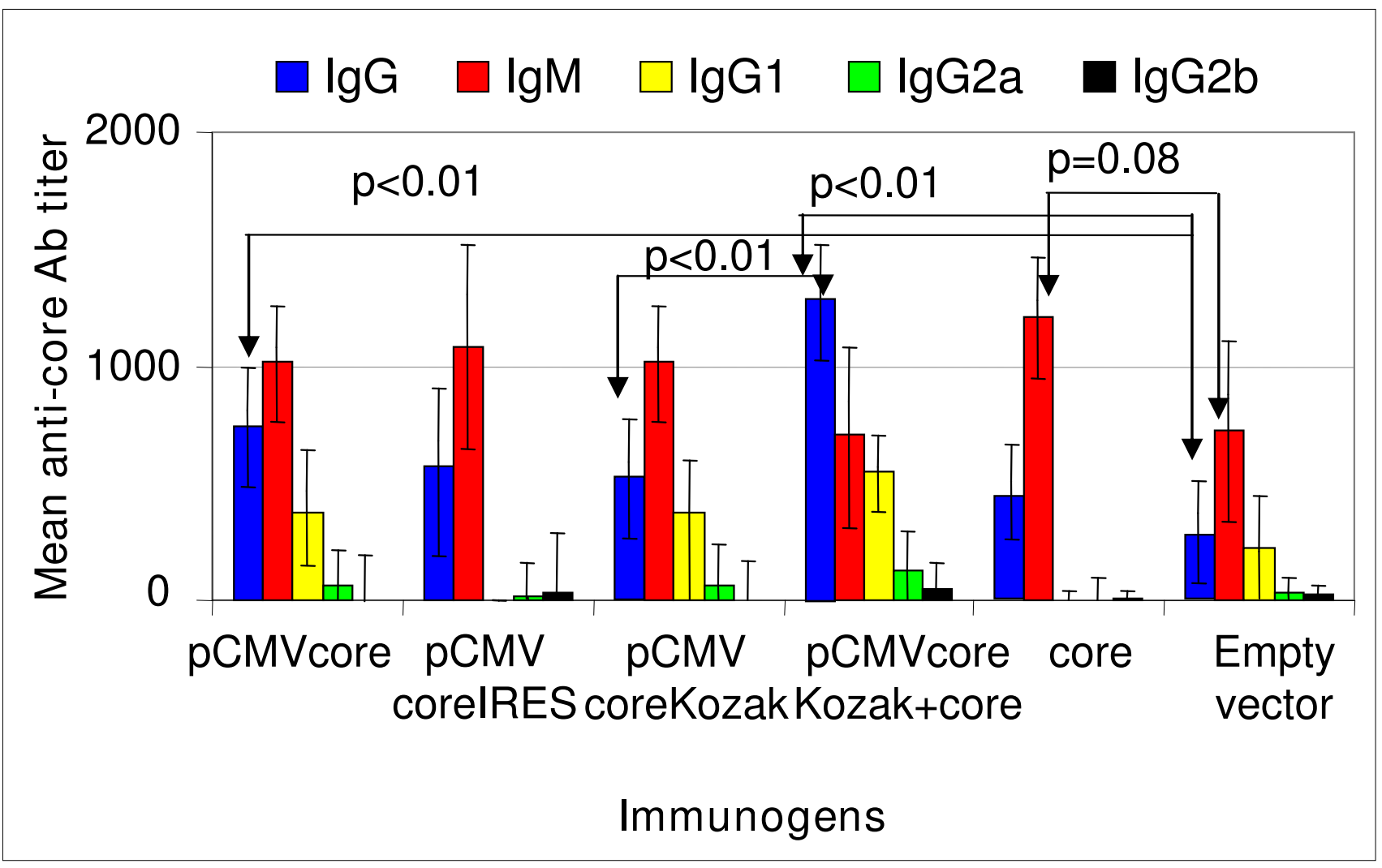

Figure 7

Spectrum of core-specific immune response. The kinetics of $\lg G$, IgM, IgG I, IgG2a and IgG2b response to core aa I-98 after immunization with different immunogens. 
a broad range of cellular proteins and influences numerous host cell functions [31,32,39,71,84,85]. Of importance for $\mathrm{HCV}$ vaccine design was to find to what extent the immune response to HCV core in DNA immunization is influenced (positively, or negatively) by the level of core expression as determined by gene dose (i), and gene expression efficacy (ii).

The first issue was addressed in a series of immunizations in which the same dose of HCV core was given as a single or split into multiple injections. We and others have earlier observed that repeated HCV core gene boosts do not lead to an enhancement of core-specific immune response $[42,46,68]$. On the contrary, both core-specific IFN- $\gamma$ and IL-2 production [68] and anti-core antibody response $[2,46,64]$ appear to be down-regulated. Here as well, the overall comparison between immunizations carried out by single and multiple core gene injections in different mouse strains demonstrated that the outcomes of immunization with one $100 \mu \mathrm{g}$ versus two to four $25 \mu \mathrm{g}$ core gene doses were quite similar (Fig. 4; see also the summary in Additional file 2). Furthermore, antibody response was not boosted; T-cell proliferative response and core-specific IFN- $\gamma$ secretion could not be boosted beyond the levels reached after the initial two injections, and core-specific IL-2 secretion even appeared to be suppressed. Thus, core-specific immune response can be achieved after single DNA immunization, while repeated core gene administration may actually suppress core-specific immunity.

The issue of translation efficacy was assessed in singledose immunizations with plasmids directing different levels of HCV core expression. There are different ways to increase the level of gene expression efficacy such as the use of strong promoters, optimal species-specific codons, and manipulations with RNA folding [78,78,79]. An important factor is the efficacy of translation initiation. In the CAP-dependent translation of mammalian genes it is determined by sequences flanking the AUG initiator codon. High levels of translation are achieved with the Kozak sequence, a guanine at position +4 and an adenine at -3 from AUG $[86,87]$. The alternative mechanisms of initiation site selection on eukaryotic cellular and viral mRNAs, also of HCV, include the translation initiation from IRESs (internal ribosome entry sites/segments) [88]. Located in the 5'-UTR region of viral genome, HCV IRES is optimized to hijack the ribosomes and translation factors from the host for the translation of HCV polyprotein [89]. Core is tightly involved in the IRES-mediated regulation of HCV translation with several regulatory signals localized in both core protein and core coding sequence $[24,90,91]$. Thus, the 5 '-end of HCV genome incorporating 5'-UTR and core coding sequence were harmonized during evolution to provide for the levels of core expression essential for the virus.

Both CAP and IRES translation initiation options were employed in the design of core DNA immunogens. Eukaryotic expression vectors were constructed encoding core of $\mathrm{HCV} 1 \mathrm{~b}$ without translation initiation signal (pCMVcore), core preceded by the 5'-UTR of HCV 1b isolate $\mathrm{AD}$ (pCMVcoreIRES), and core preceded by the consensus Kozak sequence (pCMVcoreKozak). The latter directed the expression of 35-fold more core than the gene devoid of the translation initiation signals, and 16-fold more core than the gene regulated by IRES. However, despite a considerable difference in the core expression capacity, Kozak- and IRES-regulated DNA immunogens induced similar levels of core-specific IFN- $\gamma$ secretion (Fig. 5C). More so, while IL-2 secretion was somewhat higher in mice immunized with highly expressing pCMVcoreKozak, a T-cell proliferative response to core- and corederived peptides was stronger in mice immunized with pCMVcoreIRES (Fig. 5B). Thus, high core expression levels did not promote a better core specific cellular response.

DNA-based immunization can induce potent antibody response including virus neutralizing antibodies [92-96]. However, no significant antibody response has ever been induced in core gene immunization unless it was followed by the protein boost $[2,64]$. Anti-core antibody titers obtained here after immunization with both CAP- and IRES-regulated core genes were also low. Interestingly, however, significantly higher titers of anti-core antibodies were obtained in mice that received the least expressed core gene devoid of any translation regulation signals (pCMV core; Figs. 5A, 7). Thus, the use of highly expressing HCV core DNA did not promote an effective core-specific antibody response.

Altogether, this points to possible adverse effects of the high-level as well as of the prolonged HCV core gene expression. We have additional data in support of this concept from immunization of C57BL/6 mice with a synthetic truncated HCV core gene devoid of HCV core nucleotide-sequence dependent regulatory signals. The latter expressed HCV 1b core at five to six-fold lower levels than the viral full-length core gene [97], but nevertheless, was capable of inducing potent core-specific cellular and antibody response http://www.meetingsmanagement.com/ dna_2004/index.htm[98].

DNA immunization with antigens co-expressed in natural virus infection can result in inhibition of both protein expression and specific immune response [99]. More so, pathological effects were reported of the repeated immunization with certain microbial genes, for example the 
hsp60 gene of Mycobacterium that causes necrotizing bronchointerstitial pneumonia and bronchiolitis in healthy mouse recipients, and multifocal regions of cellular necrosis in lungs when applied therapeutically $[100,101]$. HCV core is the factor of $\mathrm{HCV}$ pathogenicity. It activates cellular and viral promoters [102], induces ER- and mitochondrial stress $[103,104]$, regulates apoptosis $[105,106]$, tumorigenesis $[107,108]$, and induces abnormal lipid metabolism [109]. In experimental systems, core expression leads to the development of diverse pathological effects including CD4+ T-cell depletion, liver steatosis, insulin resistance, and hepatocellular carcinoma $[33,110]$. One of the notable although controversial features is the capacity of HCV core to suppresses host immunity $[32,39,84,85]$. These features of HCV core may explain why here a better immune response was achieved after single immunization with vectors providing for comparatively low HCV core expression.

Altogether, this points to the necessity to devise alternative immunization regimens that would help to circumvent possible adverse effects of HCV core.

Many approaches can be pursued, with DNA vaccination combined with heterologous protein or recombinant viral boosts considered as the most promising [11]. The principle of this strategy is to prime T-cells to be antigen-specific and then, upon repeated exposure to a specific antigen, induce a rapid T-cell expansion. In heterologous boosts, the encoded antigen is delivered in a different form/different vehicle [111]. DNA plasmids are perfectly fit for priming since they are internalized by antigen presenting cells and can induce antigen presentation via MHC class I or class II. Such heterologous regimens can be effective when infection occurs with both viral particles and virusinfected cells, and neither cellular, nor antibody response is sufficient for sterilizing protection or viral clearance, if acting alone. This approach may help to circumvent the negative effects of intracellular core expression. Indeed, here, the heterologous DNA-prime/protein boost strategy was shown to be advantageous to both immunizations with core DNA and with the recombinant core protein (Figs. 6, 7). Protein alone performed even worse than single DNA injections (Figs. 6, 7). Only the heterologous DNA-prime-protein boost regimen induced a significant core-specific antibody production and potent T-cell response of mainly Th1-profile. This may be beneficial since most correlates of spontaneous HCV clearance are Th1-oriented [32,39,84,85].

\section{Conclusion}

This data suggests that the administration of highly expressed HCV core gene, as well as repeated core gene injections may hamper core-specific immune response. The boosting effect of repeated core gene injections is transient as it disappears with subsequent injections. One possible way to enhance core-specific response is to deliver limited intracellular amounts of core, either by giving lower plasmid doses, or by giving vectors with low expression efficacy. An additional option is the use of heterologous DNA prime/protein boost regimen that leads to potent immune response of a mixed Th1/Th2-type. We are currently testing if transient $\mathrm{HCV}$ core gene expression and acquisition of anti-HCV core immunity affect the immune status and functionality of the immune system in gene recipients.

\section{Competing interests}

The authors declare that they have no competing interests.

\section{Authors' contributions}

IS and EK constructed plasmids and screened their immunogenicity; EA did experiments on expression and wrote a draft of the manuscript; ES and EI carried out quantifications of core expression; DS and NP did immunological experiments; RB conducted the immunocytochemistry; MI was involved with the immunological experiments, statistical evaluations and worked with the manuscript; TK and PP give useful scientific advice and revised the manuscript. All authors read and approved the final manuscript.

\section{Additional material}

\section{Additional file 1}

Establishment of calibration curves for quantification of core expression in vitro. Recombinant core aa 1-173 in serial dilutions in the range of 10 to $25 \mathrm{ng}(\mathrm{A}), 10$ to $100 \mathrm{ng}$ (B), or 12.5 to $100 \mathrm{ng}$ (C) was loaded on $15 \%$ SDS-PAAG and resolved by gel electrophoresis together with the study samples. Proteins were transferred to PVDF membrane and subjected to Western blotting with core-specific rabbit antibodies, and secondary anti-rabbit HRP-conjugated antibodies (DAKOPatts). Signals were registered using $X$-ray films and ECL detection system, images were saved, scanned, and signal of individual band corresponding to core was quantified by Image J http://rsb.info.nih.gov, and calibration curves were built (D).

Click here for file

[http://www.biomedcentral.com/content/supplementary/14790556-7-7-S1.ppt]

\section{Additional file 2}

Summary on core-specific immune responses in $B A L B / c$ and $C 57 B L / 6$ mice. Summarized data of immunization experiments performed in $B A L B / c$ and C57BL6 mice. The empty vector immunized group and the control group are composed of a mixture of BALB/c $(n=7)$ and C57BLG $(n=12)$ mice. All the other groups had been described in Figures 4 to 6. Click here for file

[http://www.biomedcentral.com/content/supplementary/14790556-7-7-S2.ppt] 


\section{Acknowledgements}

We thank Prof. Eva Stankevica and her group for the oligonucleotide synthesis and automatic sequencing and Ms. Natalija Gabrusheva and Ms. Irena Timofeeva for technical assistance. This work was supported by grants from the Latvian Council of Science 05.1626, ERAF VPDI/ERAF/CFLA/05/ APK/2.5.1./000021/0 I0, EU \#05-1000004-7748, the European Social Fund (ESF), the New Visby program of the Swedish Institute, CompuVac grant \#LSHB-CT-2004-005246 and the Russian Foundation for Basic Research \#08-04-0I 107-a.

\section{References}

I. Lauer GM, Walker BD: Hepatitis C virus infection. N Engl J Med 200I, 345:4I-52.

2. Tokushige K, Wakita T, Pachuk C, Moradpour D, Weiner DB, Zurawski VR Jr, Wands JR: Expression and immune response to hepatitis C virus core DNA-based vaccine constructs. Hepatology 1996, 24:14-20.

3. Cox GM, Lawless MC, Cassin SP, Geoghegan TW: Syringe exchanges: a public health response to problem drug use. Ir Med J 2000, 93:143-146.

4. Koziel MJ, Dudley D, Wong JT, Dienstag J, Houghton M, Ralston R, Walker BD: Intrahepatic cytotoxic T lymphocytes specific for hepatitis $\mathbf{C}$ virus in persons with chronic hepatitis. J Immunol 1992, 149:3339-3344.

5. Theodore D, Fried MW: Natural history and disease manifestations of hepatitis C infection. Curr Top Microbiol Immunol 2000, 242:43-54

6. Wong DK, Dudley DD, Afdhal NH, Dienstag J, Rice CM, Wang L, Houghton M, Walker BD, Koziel MJ: Liver-derived CTL in hepatitis $C$ virus infection: breadth and specificity of responses in a cohort of persons with chronic infection. J Immunol 1998, 160:1479-1488.

7. Bowen DG, Walker CM: Mutational escape from CD8+ T cell immunity: HCV evolution, from chimpanzees to man. J Exp Med 2005, 20I: 1709-17|4.

8. Diepolder HM, Zachoval R, Hoffmann RM, Jung MC, Gerlach T, Pape GR: The role of hepatitis C virus specific CD4+ $T$ lymphocytes in acute and chronic hepatitis C. J Mol Med 1996, 74:583-588.

9. Logvinoff C, Major ME, Oldach D, Heyward S, Talal A, Balfe P, Feinstone SM, Alter H, Rice CM, McKeating JA: Neutralizing antibody response during acute and chronic hepatitis $C$ virus infection. Proc Natl Acad Sci USA 2004, I 0 I: I0 I 49-10154.

10. Umemura T, Wang RY, Schechterly C, Shih JW, Kiyosawa K, Alter HJ: Quantitative analysis of anti-hepatitis $C$ virus antibodysecreting B cells in patients with chronic hepatitis C. Hepatology 2006, 43:91-99.

II. Wintermeyer P, Wands JR: Vaccines to prevent chronic hepatitis $C$ virus infection: current experimental and preclinical developments. J Gastroenterol 2007, 42:424-432.

12. Firbas C, Jilma B, Tauber E, Buerger V, Jelovcan S, Lingnau K, Buschle $M$, Frisch J, Klade CS: Immunogenicity and safety of a novel therapeutic hepatitis $\mathrm{C}$ virus (HCV) peptide vaccine: a randomized, placebo controlled trial for dose optimization in 128 healthy subjects. Vaccine 2006, 24:4343-4353.

13. Klade CS, Wedemeyer H, Berg T, Hinrichsen H, Cholewinska G, Zeuzem S, Blum H, Buschle M, Jelovcan S, Buerger V, Tauber E, Frisch J, Manns MP: Therapeutic vaccination of chronic hepatitis $C$ nonresponder patients with the peptide vaccine IC4I. Gastroenterology 2008, 134:1385-1395.

14. Schlaphoff $V$, Klade CS, Jilma B, Jelovcan SB, Cornberg M, Tauber E, Manns MP, Wedemeyer $\mathrm{H}$ : Functional and phenotypic characterization of peptide-vaccine-induced HCV-specific CD8+ T cells in healthy individuals and chronic hepatitis $C$ patients. Vaccine 2007, 25:6793-6806.

15. Yutani S, Yamada A, Yoshida K, Takao Y, Tamura M, Komatsu N, Ide T, Tanaka M, Sata M, Itoh K: Phase I clinical study of a personalized peptide vaccination for patients infected with hepatitis $C$ virus (HCV) Ib who failed to respond to interferon-based therapy. Vaccine 2007, 25:7429-7435.

16. Nevens F, Roskams T, Van Vlierberghe H, Horsmans Y, Sprengers D, Elewaut A, Desmet V, Leroux-Roels G, Quinaux E, Depla E, Dincq S, Stichele $C$ Vander, Maertens G, Hulstaert F: A pilot study of ther- apeutic vaccination with envelope protein $E I$ in 35 patients with chronic hepatitis C. Hepatology 2003, 38: 1289-1296.

17. Shiina M, Rehermann B: Cell culture-produced hepatitis $\mathbf{C}$ virus impairs plasmacytoid dendritic cell function. Hepatology 2008, 47:385-395

18. Folgori A, Capone S, Ruggeri L, Meola A, Sporeno E, Ercole BB, Pezzanera M, Tafi R, Arcuri M, Fattori E, Lahm A, Luzzago A, Vitelli A, Colloca S, Cortese R, Nicosia A: A T-cell HCV vaccine eliciting effective immunity against heterologous virus challenge in chimpanzees. Nat Med 2006, I 2:190-197.

19. Grakoui A, McCourt DW, Wychowski C, Feinstone SM, Rice CM: Characterization of the hepatitis $C$ virus-encoded serine proteinase: determination of proteinase-dependent polyprotein cleavage sites. J Virol 1993, 67:2832-2843.

20. Hijikata M, Mizushima H, Tanji Y, Komoda Y, Hirowatari Y, Akagi T, Kato N, Kimura K, Shimotohno K: Proteolytic processing and membrane association of putative nonstructural proteins of hepatitis C virus. Proc Natl Acad Sci USA 1993, 90:10773-10777.

21. Houghton M, Selby M, Weiner A, Choo QL: Hepatitis C virus: structure, protein products and processing of the polyprotein precursor. Curr Stud Hematol Blood Transfus 1994: I-I I.

22. Davis GL: Hepatitis $\mathbf{C}$ virus genotypes and quasispecies. $\mathrm{Am} J$ Med 1999, 107:2IS-26S.

23. Fan Z, Yang QR, Twu JS, Sherker AH: Specific in vitro association between the hepatitis $C$ viral genome and core protein. J Med Virol 1999, 59:131-134.

24. Shimoike T, Mimori S, Tani H, Matsuura Y, Miyamura T: Interaction of hepatitis C virus core protein with viral sense RNA and suppression of its translation. / Virol 1999, 73:97| 8-9725.

25. Takahashi K, Kishimoto S, Yoshizawa H, Okamoto H, Yoshikawa A, Mishiro S: p26 protein and 33-nm particle associated with nucleocapsid of hepatitis $\mathbf{C}$ virus recovered from the circulation of infected hosts. Virology 1992, 191:43 I-434.

26. Wang C, Le SY, Ali N, Siddiqui A: An RNA pseudoknot is an essential structural element of the internal ribosome entry site located within the hepatitis $C$ virus 5 ' noncoding region. RNA 1995, I:526-537.

27. Blanchard E, Hourioux C, Brand D, Ait-Goughoulte M, Moreau A, Trassard S, Sizaret PY, Dubois F, Roingeard P: Hepatitis C viruslike particle budding: role of the core protein and importance of its Asp I I I. J Virol 2003, 77:10131-10138.

28. Hourioux C, Ait-Goughoulte M, Patient R, Fouquenet D, ArcangerDoudet F, Brand D, Martin A, Roingeard P: Core protein domains involved in hepatitis $C$ virus-like particle assembly and budding at the endoplasmic reticulum membrane. Cell Microbiol 2007, 9: $1014-1027$

29. Roingeard P, Hourioux $C$ : Hepatitis $\mathbf{C}$ virus core protein, lipid droplets and steatosis. J Viral Hepat 2008, 15:157-164.

30. Basu A, Meyer K, Ray RB, Ray R: Hepatitis C virus core protein is necessary for the maintenance of immortalized human hepatocytes. Virology 2002, 298:53-62.

31. Giannini C, Brechot C: Hepatitis C virus biology. Cell Death Differ 2003, I0(Suppl I):S27-S38.

32. Isaguliants MG: Hepatitis $\mathbf{C}$ virus clearance: the enigma of failure despite an impeccable survival strategy. Curr Pharm Biotechnol 2003, 4:169-183.

33. Mori $\mathrm{Y}$, Moriishi $\mathrm{K}$, Matsuura $\mathrm{Y}$ : Hepatitis $\mathbf{C}$ virus core protein: its coordinate roles with PA28gamma in metabolic abnormality and carcinogenicity in the liver. Int J Biochem Cell Biol 2008, 40: I 1437-1442.

34. Maillard P, Krawczynski K, Nitkiewicz J, Bronnert C, Sidorkiewicz M, Gounon P, Dubuisson J, Faure G, Crainic R, Budkowska A: Nonenveloped nucleocapsids of hepatitis $C$ virus in the serum of infected patients. / Virol 200I, 75:8240-8250.

35. Jackson M, Smith B, Bevitt DJ, Steward M, Toms GL, Bassendine MF, Diamond AG: Comparison of cytotoxic T-lymphocyte responses to hepatitis $C$ virus core protein in uninfected and infected individuals. J Med Virol 1999, 58:239-246.

36. Wang YF, Brotman B, Andrus L, Prince AM: Immune response to epitopes of hepatitis C virus (HCV) structural proteins in HCV-infected humans and chimpanzees. J Infect Dis 1996, I 73:808-821.

37. Elmowalid GA, Qiao M, Jeong SH, Borg BB, Baumert TF, Sapp RK, Hu $Z$, Murthy K, Liang TJ: Immunization with hepatitis $C$ virus-like particles results in control of hepatitis $\mathbf{C}$ virus infection in chimpanzees. Proc Natl Acad Sci USA 2007, 104:8427-8432. 
38. Shata MT, Anthony DD, Carlson NL, Andrus L, Brotman B, Tricoche $\mathrm{N}$, McCormack $\mathrm{P}$, Prince $\mathrm{A}$ : Characterization of the immune response against hepatitis $C$ infection in recovered, and chronically infected chimpanzees. J Viral Hepat 2002, 9:400-4I0.

39. Thimme R, Bukh J, Spangenberg HC, Wieland S, Pemberton J, Steiger C, Govindarajan S, Purcell RH, Chisari FV: Viral and immunological determinants of hepatitis $\mathbf{C}$ virus clearance, persistence, and disease. Proc Natl Acad Sci USA 2002, 99: I566I- I5668.

40. Alvarez-Lajonchere L, Gonzalez M, Alvarez-Obregon JC, Guerra I, Vina A, costa-Rivero N, Musacchio A, Morales J, Dueñas-Carrera S: Hepatitis $C$ virus (HCV) core protein enhances the immunogenicity of a co-delivered DNA vaccine encoding HCV structural antigens in mice. Biotechnol Appl Biochem 2006, 44:9-I7.

41. Geissler M, Gesien A, Tokushige K, Wands JR: Enhancement of cellular and humoral immune responses to hepatitis $C$ virus core protein using DNA-based vaccines augmented with cytokine-expressing plasmids. J Immunol |997, I 58: |23 |- 1237.

42. Lagging LM, Meyer K, Hoft D, Houghton M, Belshe RB, Ray R: Immune responses to plasmid DNA encoding the hepatitis C virus core protein. J Virol 1995, 69:5859-5863.

43. Shirai M, Okada H, Nishioka M, Akatsuka T, Wychowski C, Houghten $R$, Pendleton CD, Feinstone SM, Berzofsky JA: An epitope in hepatitis $\mathbf{C}$ virus core region recognized by cytotoxic $\mathbf{T}$ cells in mice and humans. J Virol 1994, 68:3334-3342.

44. Vidalin O, Tanaka E, Spengler U, Trepo C, Inchauspe G: Targeting of hepatitis $\mathrm{C}$ virus core protein for MHC I or MHC II presentation does not enhance induction of immune responses to DNA vaccination. DNA Cell Biol 1999, I 8:6 I I-62 I.

45. Encke J, zu Putlitz J, Stremmel W, Wands JR: CpG immuno-stimulatory motifs enhance humoral immune responses against hepatitis $\mathbf{C}$ virus core protein after DNA-based immunization. Arch Virol 2003, I 48:435-448.

46. Duenas-Carrera S, Alvarez-Lajonchere L, Alvarez-Obregon JC, Herrera A, Lorenzo LJ, Pichardo D, Morales J: A truncated variant of the hepatitis $C$ virus core induces a slow but potent immune response in mice following DNA immunization. Vaccine 2000, 19:992-997.

47. Dunachie SJ, Walther M, Epstein JE, Keating S, Berthoud T, Andrews L, Andersen RF, Bejon P, Goonetilleke N, Poulton I, Webster DP, Butcher G, Watkins K, Sinden RE, Levine GL, Richie TL, Schneider J, Kaslow D, Gilbert SC, Carucci DJ, Hill AV: A DNA prime-modified vaccinia virus ankara boost vaccine encoding thrombospondin-related adhesion protein but not circumsporozoite protein partially protects healthy malarianaive adults against Plasmodium falciparum sporozoite challenge. Infect Immun 2006, 74:5933-5942.

48. McConkey SJ, Reece WH, Moorthy VS, Webster D, Dunachie S, Butcher G, Vuola JM, Blanchard TJ, Gothard P, Watkins K, Hannan CM, Everaere S, Brown K, Kester KE, Cummings J, Williams J, Heppner DG, Pathan A, Flanagan K, Arulanantham N, Roberts MT, Roy M, Smith GL, Schneider J, Peto T, Sinden RE, Gilbert SC, Hill AV: Enhanced $T$-cell immunogenicity of plasmid DNA vaccines boosted by recombinant modified vaccinia virus Ankara in humans. Nat Med 2003, 9:729-735

49. Kim HD, Jin JJ, Maxwell JA, Fukuchi K: Enhancing Th2 immune responses against amyloid protein by a DNA prime-adenovirus boost regimen for Alzheimer's disease. Immunol Lett 2007, I I 2:30-38.

50. Santra S, Sun Y, Parvani JG, Philippon V, Wyand MS, Manson K, Gomez-Yafal A, Mazzara G, Panicali D, Markham PD, Montefiori DC, Letvin NL: Heterologous prime/boost immunization of rhesus monkeys by using diverse poxvirus vectors. J Virol 2007, 81:8563-8570.

51. Steensels M, Bublot M, Van Borm S, De Vriese J, Lambrecht B, Richard-Mazet A, Chanavat-Bizzini S, Duboeuf M, Le Gros FX, van den Berg T: Prime-boost vaccination with a fowlpox vector and an inactivated avian influenza vaccine is highly immunogenic in Pekin ducks challenged with Asian H5NI HPAl. Vaccine 2009, 27:646-654.

52. Desjardins D, Huret C, Dalba C, Kreppel F, Kochanek S, Cosset FL, Tangy F, Klatzmann D, Bellier B: Recombinant retrovirus-like particle forming DNA vaccines in prime-boost immunization and their use for hepatitis $\mathbf{C}$ virus vaccine development. J Gene Med 2009, I I(4):3 I3-25.

53. Buonaguro L, Devito C, Tornesello ML, Schroder U, Wahren B, Hinkula J, Buonaguro FM: DNA-VLP prime-boost intra-nasal immunization induces cellular and humoral anti-HIV-I systemic and mucosal immunity with cross-clade neutralizing activity. Vaccine 2007, 25:5968-5977.

54. Kennedy JS, Co M, Green S, Longtine K, Longtine J, O'Neill MA Adams JP, Rothman AL, Yu Q, Johnson-Leva R, Pal R, Wang S, Lu S, Markham P: The safety and tolerability of an HIV-I DNA prime-protein boost vaccine (DP6-00I) in healthy adult volunteers. Vaccine 2008, 26:4420-4424

55. Duenas-Carrera S: DNA vaccination against hepatitis C. Curr Opin Mol Ther 2004, 6: | 46- I50.

56. Li YP, Kang HN, Babiuk LA, Liu Q: Elicitation of strong immune responses by a DNA vaccine expressing a secreted form of hepatitis $\mathbf{C}$ virus envelope protein $\mathrm{E} 2$ in murine and porcine animal models. World J Gastroenterol 2006, I 2:7 I26-7/35.

57. Galloway DR, Baillie L: DNA vaccines against anthrax. Expert Opin Biol Ther 2004, 4: 166 I-1667.

58. Skeiky YA, Sadoff JC: Advances in tuberculosis vaccine strategies. Nat Rev Microbiol 2006, 4:469-476.

59. Tanghe A, Dangy JP, Pluschke G, Huygen K: Improved Protective Efficacy of a Species-Specific DNA Vaccine Encoding Mycolyl-Transferase Ag85A from Mycobacterium ulcerans by Homologous Protein Boosting. PLoS Negl Trop Dis 2008, 2:e 199.

60. Moore OC, Bosarge JR, Quin LR, McDaniel LS: Enhanced protective immunity against pneumococcal infection with PspA DNA and protein. Vaccine 2006, 24:5755-576I.

6I. Liang R, Hurk JV van den, Landi A, Lawman Z, Deregt D, Townsend $H$, Babiuk LA, van Drunen Littel-van den Hurk S: DNA prime protein boost strategies protect cattle from bovine viral diarrhea virus type 2 challenge. J Gen Virol 2008, 89:453-466.

62. Liang R, Hurk JV van den, Zheng C, Yu H, Pontarollo RA, Babiuk LA, van Drunen Littel-van den Hurk S: Immunization with plasmid DNA encoding a truncated, secreted form of the bovine viral diarrhea virus E2 protein elicits strong humoral and cellular immune responses. Vaccine 2005, 23:5252-5262.

63. Lu S: Immunogenicity of DNA vaccines in humans: it takes two to tango. Hum Vaccin 2008, 4:449-452.

64. Hu GJ, Wang RY, Han DS, Alter HJ, Shih JW: Characterization of the humoral and cellular immune responses against hepatitis $\mathbf{C}$ virus core induced by DNA-based immunization. Vaccine 1999, I7:3160-3170.

65. Mokhonov VV, Novikov DV, Samokhvalov El, Shatalov AG, Selivanov NA, Prilipov AG, L'vov DK: [Genome analysis of hepatitis C virus strain 274933RU isolated in Russian Federation]. Vopr Virusol 2002, 47:9-12.

66. Sominskaya I, Alekseeva E, Skrastina D, Mokhonov V, Starodubova E Jansons J, Levi M, Prilipov A, Kozlovska T, Smirnov V, Pumpens P, Isaguliants MG: Signal sequences modulate the immunogenic performance of human hepatitis $\mathbf{C}$ virus $\mathbf{E 2}$ gene. Mol Immunol 2006, 43:1941-1952.

67. Rispeter K, Lu M, Lechner S, Zibert A, Roggendorf M: Cloning and characterization of a complete open reading frame of the hepatitis $\mathbf{C}$ virus genome in only two cDNA fragments. J Gen Virol I997, 78(Pt I I):275I-2759.

68. Isaguliants MG, Petrakova NV, Kashuba EV, Suzdaltzeva YG, Belikov SV, Mokhonov VV, Prilipov AG, Matskova L, Smirnova IS, Jolivet-Reynaud $\mathrm{C}$, Nordenfelt $\mathrm{E}$ : Immunization with hepatitis $\mathbf{C}$ virus core gene triggers potent $T$-cell response, but affects CD4+ $T$ cells. Vaccine 2004, 22: 1656-1665.

69. Mihailova M, Fiedler M, Boos M, Petrovskis I, Sominskaya I, Roggendorf M, Viazov S, Pumpens P: Preparation of hepatitis $C$ virus structural and non-structural protein fragments and studies of their immunogenicity. Protein Expr Purif 2006, 50:43-48.

70. Petrakova NV, Kalinina TI, Khudiakov I, Gazina EV, Smirnov VD: [Preparation and purification of a polypeptide containing antigenic determinants of hepatitis C core protein]. Vopr Virusol 1997, 42:208-212.

7I. McLauchlan J: Properties of the hepatitis $\mathbf{C}$ virus core protein: a structural protein that modulates cellular processes. J Viral Hepat 2000, 7:2-14.

72. Yasui K, Wakita T, Tsukiyama-Kohara K, Funahashi SI, Ichikawa M, Kajita T, Moradpour D, Wands JR, Kohara M: The native form and maturation process of hepatitis $\mathbf{C}$ virus core protein. J Virol 1998, 72:6048-6055.

73. Ravaggi A, Natoli G, Primi D, Albertini A, Levrero M, Cariani E: Intracellular localization of full-length and truncated hepatitis $C$ 
virus core protein expressed in mammalian cells. J Hepatol 1994, 20:833-836

74. Suzuki R, Matsuura Y, Suzuki T, Ando A, Chiba J, Harada S, Saito I, Miyamura T: Nuclear localization of the truncated hepatitis $C$ virus core protein with its hydrophobic $C$ terminus deleted. J Gen Virol I995, 76(Pt I):53-6I.

75. Mosmann TR, Coffman RL: THI and TH2 cells: different patterns of lymphokine secretion lead to different functional properties. Annu Rev Immunol 1989, 7:|45-173.

76. Pokorna D, Rubio I, Muller M: DNA-vaccination via tattooing induces stronger humoral and cellular immune responses than intramuscular delivery supported by molecular adjuvants. Genet Vaccines Ther 2008, 6:4.

77. Nowicki MJ, Balistreri WF: The hepatitis $\mathbf{C}$ virus: identification, epidemiology, and clinical controversies. J Pediatr Gastroenterol Nutr 1995, 20:248-274.

78. Garmory HS, Brown KA, Titball RW: DNA vaccines: improving expression of antigens. Genet Vaccines Ther 2003, I:2

79. Sturtz FG, Li Y, Shulok J, Snodgrass HR, Chen Xz: A Nonviral Cytoplasmic T7 Autogene System and Its Applications in DNA Vaccination. 2000:323-333.

80. Deml L, Bojak A, Steck S, Graf M, Wild J, Schirmbeck R, Wolf H, Wagner $R$ : Multiple effects of codon usage optimization on expression and immunogenicity of DNA candidate vaccines encoding the human immunodeficiency virus type I Gag protein. IVirol 2001, 75:1099/-II00I.

81. Stratford R, Douce G, Zhang-Barber L, Fairweather N, Eskola J, Dougan G: Influence of codon usage on the immunogenicity of a DNA vaccine against tetanus. Vaccine 2000, 19:810-815.

82. Fu TM, Guan L, Friedman A, Schofield TL, Ulmer JB, Liu MA, Donnelly JJ: Dose dependence of CTL precursor frequency induced by a DNA vaccine and correlation with protective immunity against influenza virus challenge. J Immunol 1999, 162:4163-4170

83. Lee AH, Suh YS, Sung JH, Yang SH, Sung YC: Comparison of various expression plasmids for the induction of immune response by DNA immunization. Mol Cells 1997, 7:495-50I.

84. Bassett SE, Thomas DL, Brasky KM, Lanford RE: Viral persistence, antibody to $E I$ and E2, and hypervariable region I sequence stability in hepatitis $\mathbf{C}$ virus-inoculated chimpanzees. J Virol 1999, 73:1118-1126.

85. Rehermann B, Nascimbeni M: Immunology of hepatitis B virus and hepatitis C virus infection. Nat Rev Immunol 2005, 5:2 I 5-229.

86. Kozak M: Role of ATP in binding and migration of 405 ribosomal subunits. Cell 1980, 22:459-467.

87. Kozak M: Point mutations close to the AUG initiator codon affect the efficiency of translation of rat preproinsulin in vivo. Nature 1984, 308:241-246.

88. Jackson RJ: Alternative mechanisms of initiating translation of mammalian mRNAs. Biochem Soc Trans 2005, 33:|23|-124|.

89. Fraser CS, Doudna JA: Structural and mechanistic insights into hepatitis C viral translation initiation. Nat Rev Microbiol 2007, 5:29-38.

90. Li D, Takyar ST, Lott WB, Gowans E): Amino acids I-20 of the hepatitis C virus (HCV) core protein specifically inhibit HCV IRES-dependent translation in HepG2 cells, and inhibit both HCV. J Gen Virol 2003, 84:8I5-825.

91. Wang TH, Rijnbrand RC, Lemon SM: Core protein-coding sequence, but not core protein, modulates the efficiency of cap-independent translation directed by the internal ribosome entry site of hepatitis C virus. J Virol 2000, 74: I I 347- I I 358.

92. Wang B, Merva M, Dang K, Ugen KE, Boyer J, Williams WV, Weiner DB: DNA inoculation induces protective in vivo immune responses against cellular challenge with HIV-I antigenexpressing cells. AIDS Res Hum Retroviruses 1994, I0(Suppl 2):S35-S4I.

93. Ulmer JB, Donnelly J], Parker SE, Rhodes GH, Felgner PL, Dwarki VJ, Gromkowski SH, Deck RR, DeWitt CM, Friedman A: Heterologous protection against influenza by injection of DNA encoding a viral protein. Science 1993, 259: 1745-1749.

94. Rollman E, Hinkula J, Arteaga J, Zuber B, Kjerrstrom A, Liu M, Wahren B, Ljungberg K: Multi-subtype gp I60 DNA immunization induces broadly neutralizing anti-HIV antibodies. Gene Ther 2004, I I: I I46-I I54.

95. Faber M, Lamirande EW, Roberts A, Rice AB, Koprowski $H$, Dietzschold $B$, Schnell MJ: A single immunization with a rhab- dovirus-based vector expressing severe acute respiratory syndrome coronavirus (SARS-CoV) $S$ protein results in the production of high levels of SARS-CoV-neutralizing antibodies. I Gen Virol 2005, 86: I435-I440.

96. Bahloul C, Taieb D, Diouani MF, Ahmed SB, Chtourou Y, B'chir BI, Kharmachi $H$, Dellagi K: Field trials of a very potent rabies DNA vaccine which induced long lasting virus neutralizing antibodies and protection in dogs in experimental conditions. Vaccine 2006, 24: 1063-1072.

97. Isaguliants MG, lakimtchouk K, Petrakova NV, Yermalovich MA, Zuber AK, Kashuba VI, Belikov SV, Andersson S, Kochetkov SN, Klinman DM, Wahren B: Gene immunization may induce secondary antibodies reacting with DNA. Vaccine 2004, 22: I576-I 585.

98. Petrakova N, Yakimchuk K, Suzdaltzeva Y, Jolivet-Reynaud C, Wahren B, Isaguliants MG: "Bacterialized" gene for the C-terminus Truncated Version of Human Hepatitis $C$ virus Core Induces Potent Th2-type Immune Response in Mice. [Abstract] DNA Vaccine Conference, Monte-Carlo, Monaco I7-19 November, 2004

99. Kjerrstrom A, Hinkula J, Engstrom G, Ovod V, Krohn K, Benthin R, Wahren $B$ : Interactions of single and combined human immunodeficiency virus type I (HIV-I) DNA vaccines. Virology 200I, 284:46-6I.

100. Taylor JL, Turner OC, Basaraba RJ, Belisle JT, Huygen K, Orme IM: Pulmonary necrosis resulting from DNA vaccination against tuberculosis. Infect Immun 2003, 71:2192-2198.

10I. Turner OC, Roberts AD, Frank AA, Phalen SW, McMurray DM, Content J, Denis O, D'Souza S, Tanghe A, Huygen K, Orme IM: Lack of protection in mice and necrotizing bronchointerstitial pneumonia with bronchiolitis in guinea pigs immunized with vaccines directed against the hsp60 molecule of Mycobacterium tuberculosis. Infect Immun 2000, 68:3674-3679.

102. Ray RB, Lagging LM, Meyer K, Steele R, Ray R: Transcriptional regulation of cellular and viral promoters by the hepatitis $C$ virus core protein. Virus Res 1995, 37:209-220.

103. Li K, Prow T, Lemon SM, Beard MR: Cellular response to conditional expression of hepatitis C virus core protein in Huh7 cultured human hepatoma cells. Hepatology 2002, 35: $1237-1246$.

104. Moriya K, Nakagawa K, Santa T, Shintani Y, Fujie H, Miyoshi H, Tsutsumi T, Miyazawa T, Ishibashi K, Horie T, Imai K, Todoroki T, Kimura $\mathrm{S}$, Koike K: Oxidative stress in the absence of inflammation in a mouse model for hepatitis C virus-associated hepatocarcinogenesis. Cancer Res 200I, 61:4365-4370.

105. Hahn CS, Cho YG, Kang BS, Lester IM, Hahn YS: The HCV core protein acts as a positive regulator of fas-mediated apoptosis in a human lymphoblastoid $\mathbf{T}$ cell line. Virology 2000, 276: $127-137$

106. Ray RB, Meyer K, Ray R: Suppression of apoptotic cell death by hepatitis C virus core protein. Virology 1996, 226: 176-182.

107. Moriya K, Fujie H, Shintani Y, Yotsuyanagi H, Tsutsumi T, Ishibashi K, Matsuura $Y$, Kimura S, Miyamura T, Koike K: The core protein of hepatitis $\mathbf{C}$ virus induces hepatocellular carcinoma in transgenic mice. Nat Med 1998, 4:1065-1067.

108. Ray RB, Lagging LM, Meyer K, Ray R: Hepatitis C virus core protein cooperates with ras and transforms primary rat embryo fibroblasts to tumorigenic phenotype. J Virol 1996, 70:4438-4443.

109. Yamaguchi A, Tazuma S, Nishioka T, Ohishi W, Hyogo H, Nomura S, Chayama K: Hepatitis $C$ virus core protein modulates fatty acid metabolism and thereby causes lipid accumulation in the liver. Dig Dis Sci 2005, 50:1361-I37|

I I0. Moriya K, Yotsuyanagi H, Shintani Y, Fujie H, Ishibashi K, Matsuura Y, Miyamura T, Koike K: Hepatitis $\mathbf{C}$ virus core protein induces hepatic steatosis in transgenic mice. J Gen Virol 1997, 78(Pt 7): $1527-1531$

III. Ramshaw IA, Ramsay AJ: The prime-boost strategy: exciting prospects for improved vaccination. Immunol Today 2000 , 21:163-165. 